\title{
Career Development: Domestic Display as Imperial, Anthropological, and Social
}

\section{Trophy}

Claire Wintle

In entering a collection, an object is made newly meaningful in relation to the other objects which come to surround it and is reinvented by the interpretations bestowed upon it by its new owner (Stewart 151-65). Susan Pearce has emphasized the way in which the collected object no longer exists in a system of "living goods working in the world" (24), but becomes the "reified thoughts and feelings" of the collector (25). When those reified thoughts and feelings are viewed, however, they introduce the collector to the wider world; while the acts of collecting and caring for a collection can be intensely private experiences, they are nonetheless acts of public relations. With this in mind, collectors can select, juxtapose, and arrange their objects with calculated precision, addressing both imaginary and actual audiences to convey specific messages. This was especially true in the Victorian and Edwardian periods, when certain private homes became publicly accessible as a national obsession with the domestic lives of notable personalities grew. ${ }^{1}$

In what follows, I will explore these themes through the domestic displays of Sir Richard Carnac Temple, a colonial official who collected material culture during his service in British India. Born in 1850, he fought with the Royal Scots Fusiliers in the Second Anglo-Afghan War and the Third Anglo-Burmese War before embarking upon a successful administrative career, holding high-ranking positions in the Punjab, Mandalay, and Rangoon. In 1894 he was appointed Chief Commissioner of the Andaman and Nicobar Islands in the Bay of Bengal and charged with supervising the building of the cellular jail at the heart of the British penal colony there. Harboring profound interest in all things 
This text is published as Claire Wintle, "Career development: domestic display as imperial, anthropological and social trophy”, Victorian Studies, 50 (2), 2008, pp. 279-288. ISSN 0042-5222

(http://www.jstor.org/stable/40060327)

anthropological, Temple amassed large collections of objects from the regions in which he worked. ${ }^{2}$ These were particularly strong in teak carvings from Burma and body adornments and hunting tools from the various indigenous communities on the Andaman and Nicobar Islands.

During his lengthy career, Temple displayed many of these objects in the government buildings in which he resided. On his retirement, however, The Nash, his house at the heart of his ancestral estate in Worcestershire, became the show home for his South Asian collections. There he created a public image of his identity as a triumphant colonial chief, a "shining light" in the emerging discipline of anthropology, and a wealthy, upper-class lord of the manor (Temple to Mrs. Roberts, 6 Jan. 1914). Drawing on photographic evidence, sales inventories, and private correspondence, this essay seeks to do three things: first, provide an insight into Temple's identity as a colonial collector; second, provide a detailed example of how a small portion of the material culture removed from India during the late nineteenth century was consumed in Britain; and finally, complement and extend new scholarship re-contextualizing non-Western objects in domestic displays in the metropole. ${ }^{3}$

Just before his retirement from service in 1904, having packed up the material remnants of his career, Temple joked to his friends that he should like to see his old housekeeper's face when "she sees my 92 cases arriving in about a week" (Temple to Mrs. Roberts, 17 July 1903). Upon his return, despite the many restorations and improvements required throughout The Nash, it is clear that the arrangement and presentation of his collections was paramount. Within a year of their arrival at his estate, Temple's South Asian possessions were erected and publicly introduced; almost immediately, Temple had had 
This text is published as Claire Wintle, "Career development: domestic display as imperial, anthropological and social trophy”, Victorian Studies, 50 (2), 2008, pp. 279-288. ISSN 0042-5222

(http://www.jstor.org/stable/40060327)

photographs of his home produced and sent to friends. ${ }^{4}$ He had also hosted a party for members of the UK's Museums Association; reportedly, they were particularly appreciative of his collections from Burma and the Andaman and Nicobar Islands ("Worcester" 39, 35). And he had also invited a journalist from the World newspaper to write a feature on his domestic situation. In the article, part of the "Celebrities at Home" series, the paper's extensive readership was introduced to Temple's newly erected "Museum," "full of Burmese carvings and Indian brassware," and an "old private brewery . . converted into a billiard-room and gallery for the present baronet's collection of the arms of Oriental Savages" (“Celebrities" 442).

These public displays introduced a variety of audiences to those aspects of Temple's identity of which he was most proud. The journalist from the World, for example, immediately noted the correlations between these collections and the successes of Temple's colonial career, citing "the interior of the house, which is full of trophies and curiosities" as evidence of Temple's "connection with our Asiatic dependencies" ("Celebrities" 442). That his personal collection was particularly strong in Andamanese and Nicobarese hunting tools is telling. As Chief Commissioner of the Andaman and Nicobar Islands, Temple clearly relished the role of the imperial hunter, particularly when engaging with some of the more hostile communities in the region. In a lecture to the Society of the Arts in 1899, describing an encounter with a party of Jarawa (one such group of indigenous Andamanese), his references to hunting, combat, and warfare are notable:

We then organise an expedition of trained Indian police and friendly Andamanese to hunt for the Jarawas. Generally we catch some and bring them to the Settlement, where we feed and keep them till they are thoroughly home-sick, and then we load them up with presents ${ }^{5}$ and let them 
This text is published as Claire Wintle, "Career development: domestic display as imperial, anthropological and social trophy”, Victorian Studies, 50 (2), 2008, pp. 279-288. ISSN 0042-5222

(http://www.jstor.org/stable/40060327)

go. ... Once I recollect our party captured the enemy's camp while the enemy were capturing ours. The enemy got the best of it, because there was more loot in our camp than in theirs. ("Round" 114$)^{6}$

Temple's appropriation and display of his indigenous hunting tools from the Islands reflects this aggressive attitude and specifically emphasizes his self-styled image as the imperial chief. For the makers and users of these objects, such tools often represented Andamanese or Nicobarese control over the natural world rather than the British presence; communities from both sets of island groups predominantly used their bows, spears, and arrows for pig hunting and fishing. However, within the vocabulary of Temple's collection and the British imperial project, these objects were renamed "weapons" and the "arms of savages," emphasizing accordingly the imagined dangers endured to procure them (Temple to Mrs. Roberts, 29 Oct. 1922). Moreover, the processes of material exchange on the Islands were highly complicated and certainly object- and party-specific: some of these items may have been acquired in an encounter that satisfied both the British and Andamanese or Nicobarese parties. However, in the context of Temple's aggression and assertion of imperial authority, removing such hunting tools from the hands of the Andamanese and Nicobarese might also be perceived as a loaded act. In collecting objects to promote a sense of moral and material control over colonial subjects (Breckenridge 21), Temple often chose objects that would have been considered intrinsically masculine; his actions thus represent a symbolic emasculation of the objects' indigenous users.

Their display in The Nash made these objects and the aggressive imperialism and individual authority they symbolized public. Temple had his arsenal installed in his newly developed billiard room, along with the horns and hides of slaughtered animals from his son's latest hunting trip ("Celebrities" 442). Here, in the "nucleus of the male preserve" (Girouard 24), the tools were associated with male competition and sport. Moreover, the 
This text is published as Claire Wintle, "Career development: domestic display as imperial, anthropological and social trophy”, Victorian Studies, 50 (2), 2008, pp. 279-288. ISSN 0042-5222

(http://www.jstor.org/stable/40060327)

objects are likely to have been displayed in the trophy paradigm, a mode of display

employed by many during the period, and indeed by Temple in his previous residence on

the Andaman Islands (fig. 1). Annie Coombes and Nicholas Thomas have both read the use of the trophy layout as a political act, symbolic of a corresponding ordering of the colonial subject (Coombes 71-74; Thomas 174). Indeed, the symmetrical, carefully placed arrangement of the objects aestheticizes these tools, subjecting them to the traditions of the Western art historical canon. Such a display paradigm, in emphasizing aesthetic and formal similarities, denies the objects their differences in function and provenance, blurring, furthermore, the very different Andamanese and Nicobarese cultures from which they came. ${ }^{7}$ The hunting theme and the collector are the most prominent links among the objects, and this display accordingly functions as a trophy to Temple's colonial and masculine successes. ${ }^{8}$

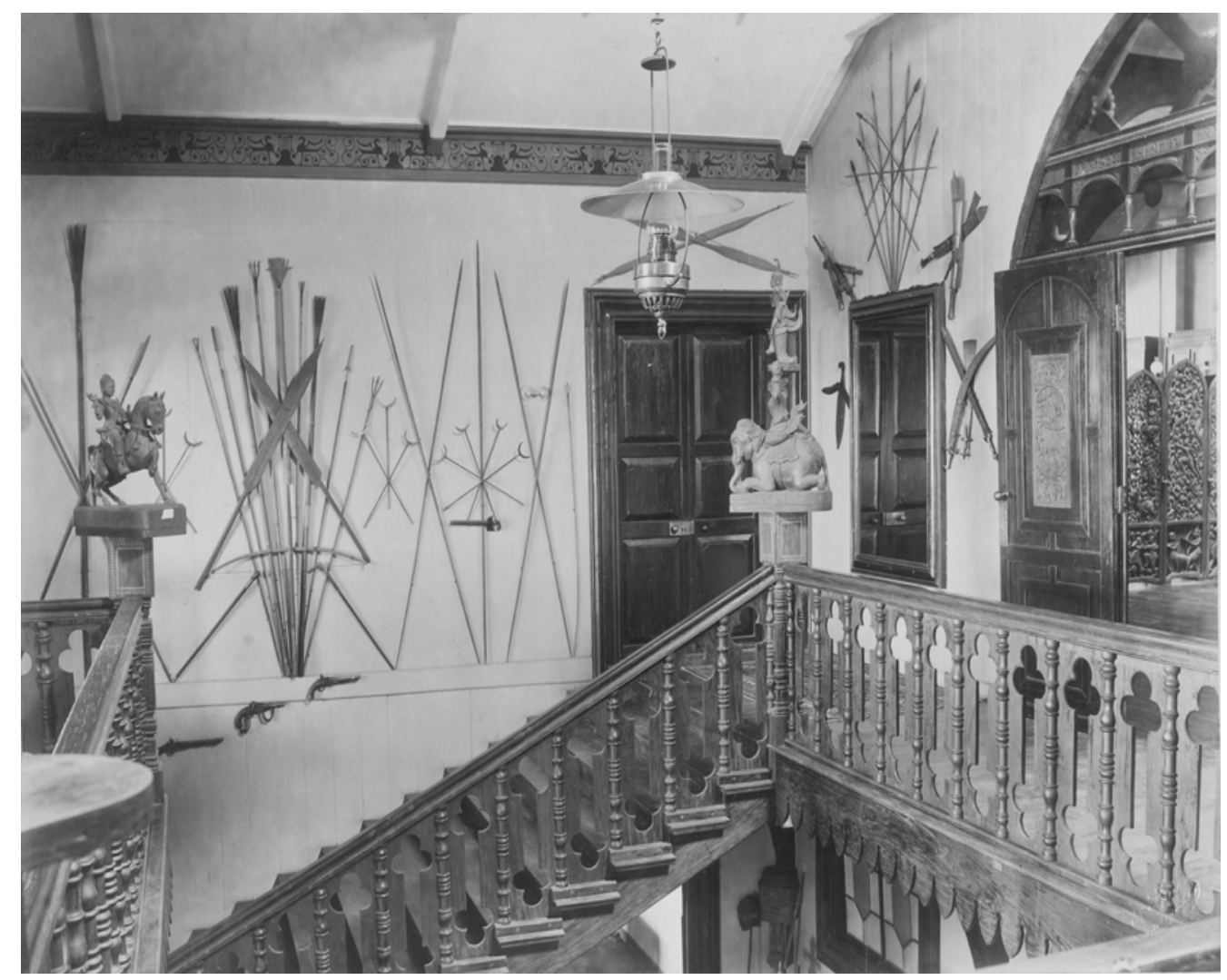

Figure 1: Philip Adolphe Klier. Central Hallway, Government House, Port Blair, Andaman Islands, c. 1895. Source: British Library: Asia, Pacific \& Africa Collections, Photo 125/2 (8) 
While these trophies announce Temple's authority over the indigenous inhabitants of the Andaman and Nicobar Islands, they also attest to the professional superiority he enjoyed over his British colleagues in the region. In the late nineteenth century, the people of the Andaman Islands, in particular, were seen as "the most primitive, or lowest in the scale of civilization, of the human race" (Owen 42). Throughout Europe, information regarding their culture was particularly prized as extreme evidence of the socioevolutionary theories which dominated scientific thought. Because of this interest, colonial officials stationed in the region competed to collect and analyze Andamanese material culture; their collections were a means of attracting praise and attention from the anthropological community in the metropole.

Temple's impact on the emerging discipline of anthropology was considerable: he actively encouraged young colonial officers to use anthropological methods before they were posted in the colonies, so that once they arrived there they might send the fruits of their research back to Britain (Kuklick 197); he was editor of the Indian Antiquary from 1892 until his death in 1931; he was president of the Anthropology Section of the British Association for the Advancement of Science; and he made important studies into Burmese spirit worship and Indian folklore. ${ }^{9}$ Not one for modesty, he once declared to a friend that in "the study of mankind . . . I am supposed to be a shining light!" (Temple to Mrs. Roberts, 6 Jan. 1914). This self-regard and reputation stood Temple in good stead in the Andaman and Nicobar Islands. His senior role within the British community in the region facilitated his anthropological endeavors while allowing him to regulate those of others.

That regulation was not always welcome. Airing grievances to his associates at the British Museum in 1895, Temple's junior colleague, Maurice Vidal Portman, told of how, as Chief Commissioner, Temple made regular use of his position to control the amount of 
This text is published as Claire Wintle, "Career development: domestic display as imperial, anthropological and social trophy”, Victorian Studies, 50 (2), 2008, pp. 279-288. ISSN 0042-5222

(http://www.jstor.org/stable/40060327)

data that was allowed to return to the scientific community in the metropole. Portman considered Temple to have a "rooted objection" to the time that some of his staff spent in studying the indigenous people (Portman to Charles Read, 2 Mar. 1895), and recalled how once, when he had happened upon two members of the elusive Jarawa community, Temple had "not let me go out with them to the Little Andaman [Island], to compare them with the Öngés, or go back with them and study them in their own country"(Portman to A. W. Franks, 15 Apr. 1895). Certainly, in many cases, Temple was supportive of his staff in their scholarly endeavors, but, as Chief Commissioner, he also had the power to prevent, postpone, and police their contact with the indigenous communities when in competition with his own.

Temple's extensive displays in The Nash and in his home on the Andaman Islands were a particularly effective way of broadcasting this authority. These objects were tangible proof of his unusual access to the various communities of the region. In an era when anthropological study was so dependent on material culture for evidence, ${ }^{10}$ the sheer scale of his collection--over 300 Andamanese and Nicobarese objects ${ }^{11}$--and its unrivaled quality as a British collection in private hands ${ }^{12}$ ensured that its display was an emblem of Temple's anthropological prowess and superiority.

Temple's domestic display of his material collections was also heavily bound up with his family heritage and class status. Once displayed in The Nash, his collections joined an established body of family heirlooms. Not only had Temple's father and grandfather collected prolifically during their own successful careers on the Indian subcontinent, but the family's longstanding wealth had enabled the amalgamation of important furniture, fine art, and manuscript collections.

In figure 2, Temple's assortment of Andamanese body adornment is presented in the anteroom of The Nash, and slotted behind his father's Indian collections that adorned the 
This text is published as Claire Wintle, "Career development: domestic display as imperial, anthropological and social trophy”, Victorian Studies, 50 (2), 2008, pp. 279-288. ISSN 0042-5222

(http://www.jstor.org/stable/40060327)

hallway. ${ }^{13}$ The circular waist belts and bands made from shells and pandanus fiber to adorn the limbs of the various indigenous people on the Islands appear to cover the entire length of the wall. This positioning of individual collections, each belonging to a different generation and presented in consecutive rooms advancing away from the threshold of the ancestral home, can be read as the symbolic accumulation of layers of significance in Temple's family heritage. The Times noted that the family line was "as old as English History" ("Death" 4); the arrangement of objects aimed to confirm this claim.

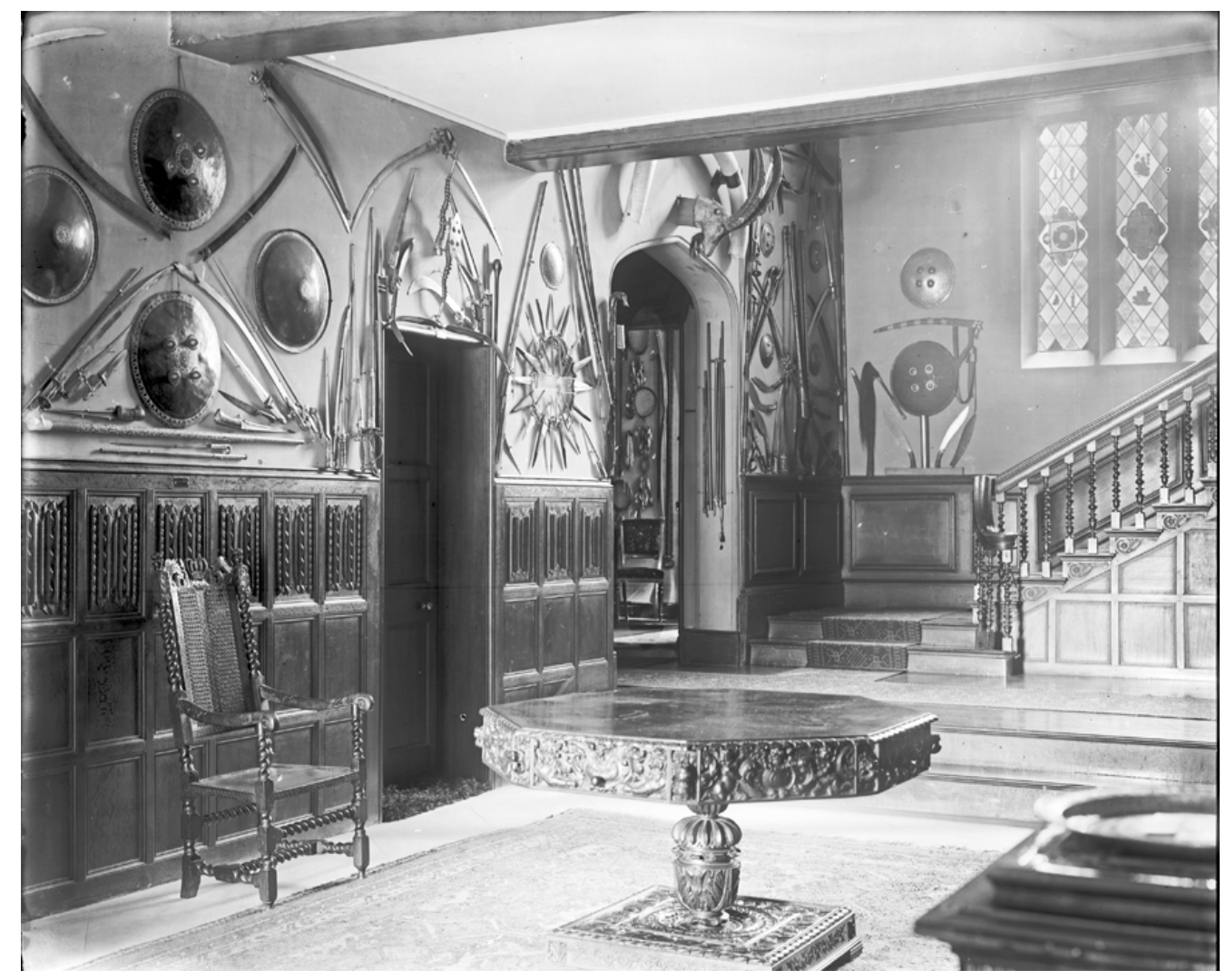

Fig. 2. [Richard Durrand Temple]. Hallway, The Nash, c. 1904. (O) Pitt Rivers Museum, University of Oxford, 1999.19.9.

Temple thought these collections were integral to the status of future generations of his family. ${ }^{14}$ When the property taxes of the First World War forced him to consider selling his entire estate and its contents, the strong relationship between his collections and his family heritage became explicit. He hoped to save his house and its contents for his grandson (Temple to Mrs. Roberts, 12 Jan. 1918), but in 1918 his worst fears were confirmed and 
This text is published as Claire Wintle, "Career development: domestic display as imperial, anthropological and social trophy”, Victorian Studies, 50 (2), 2008, pp. 279-288. ISSN 0042-5222

(http://www.jstor.org/stable/40060327)

the staggered sale of his family heirlooms began: "The poor old Nash is already gutted of its glories," he wrote, "... and in that is buried the hopes and labour of more than 40 years as far as I am concerned” (Temple to Mrs. Roberts, 12 Jan. 1918). A few months later he again lamented, "the very valuable old things-that gave [The Nash] its position as a 'principal seat' and the five libraries are gone” (Temple to Mrs. Roberts, 5 May 1918). This process culminated in a three day sale of the remaining contents of The Nash by auctioneers Knight, Frank, \& Rutley in 1922. The removal of Temple's domestic displays signified a change to the trajectory of the Temple lineage; the press coverage of that removal signified a major rupture in Temple's own public identity. ${ }^{15}$ Even in their dispersal, his objects and their expired display acted as informants about their sometime owner.

The close interrogation of case studies such as this allows us to paint a fuller picture of the British Victorian (and Edwardian) relationship with colonial goods; in doing so, such research can avoid the risk of what Douglas Lorimer has called "colonizing the Victorians" $(12-13) .{ }^{16}$ In many respects, Temple was a colonial official and upper-class gentleman typical of his time: the domestic display of his ethnographic collections was undoubtedly influenced by popular trends in interior design. But he manipulated these trends to make his own statements about both himself and the world around him, just as others must have done. Through this research we can better comprehend the consumption of non-Western material in the metropole by one individual and the pronounced interaction between the identity of the British citizen and domestic display.

University of Sussex; Brighton Museum and Art Gallery 
This text is published as Claire Wintle, "Career development: domestic display as imperial, anthropological and social trophy”, Victorian Studies, 50 (2), 2008, pp. 279-288. ISSN 0042-5222

(http://www.jstor.org/stable/40060327)

\section{NOTES}

I would like to thank Brenda Bennett-Davies of The Nash; the librarians of the Department of Prehistory and Europe at the British Museum, and the Asia, Pacific, and Africa Collections at the British Library; Meaghan Clarke and Sarah Posey for their comments on earlier versions of this paper; delegates at "Objects, Images and Imaginings: Perspectives on the Material and Visual Culture of the Andaman and Nicobar Islands” symposium, Brighton Museum and Art Gallery, for their questions and suggestions; and Julie F. Codell for organizing the 2007 NAVSA/VSAWC special session on "Material Empire: The Conflict of Collecting and Consuming Colonial Goods."

1. One sign of this obsession was the establishment of popular periodical series such as the World's

“Celebrities at Home." Cohen details the development of this celebrity profiling genre succinctly (122-25).

She also acknowledges the popular late-nineteenth-century conviction central to my own argument: for late Victorian and Edwardian citizen, "the domestic interior expressed its inhabitant's inner self" (123).

2. In addition to the personal collections studied here, Temple amassed large material collections from the indigenous communities on both the Andaman and Nicobar Islands for the benefit of cultural institutions in the UK. Major donations were made to the British Museum, the University of Cambridge Museum of Archaeology and Ethnology (now Anthropology), and the Pitt Rivers Museum.

3. See Logan 181-201.

4. See, for example, figure 2 , which is likely to have been included as one of a larger set sent to a correspondent in New Zealand.

5. The presentation of gifts of consumables such as cigarettes, metal, red cloth, and food stuffs to the Andamanese and Nicobarese peoples was a common practice by members of the British community. These are now recognized as attempts to bribe, Westernize, and manipulate their recipients.

6. See also analysis of E. H. Man's rhetoric regarding encounters with the Andamanese as "not unlike the language of guerrilla warfare" in Sen 154.

7. The indigenous inhabitants of the Andaman Islands are culturally and ethnohistorically distinct from those who live on the Nicobar Islands. Production and use of material culture on each island group and in individual communities located on both island groups is varied.

8. See Jordanova, who argues that the trophy paradigm "simultaneously expresses victory, ownership, control" (32). 
This text is published as Claire Wintle, "Career development: domestic display as imperial, anthropological and social trophy”, Victorian Studies, 50 (2), 2008, pp. 279-288. ISSN 0042-5222

(http://www.jstor.org/stable/40060327)

9. See, for example, Temple, The Thirty-Seven Nats: A Phase of Spirit-Worship Prevailing in Burma (1906); Steel, with Temple, Wide Awake Stories: A Collection of tales told by little children, between sunset and sunrise, in the Panjab and Kashmir (1884); and Temple, The Legends of the Panjâb (1884-86).

10. See van Keuren 26-39. Also see Lane Fox for one primary source stating the importance of material culture in relation to European anthropological knowledge concerning the Andamanese (451).

11. The collection from the Andaman and Nicobar Islands was eventually donated in its entirety, along with forty-three miscellaneous objects, to the Brighton Museum and Art Gallery, having failed to sell at the public auction of the Temple collections in 1922.

12. See, for example, comments made by the Museums Association in "Worcester" 35.

13. Figure 2, part of the Photograph and Manuscript Collections at the Pitt Rivers Museum, has traditionally, if tentatively, been identified as the entrance hall of Rushmore, Augustus Henry Lane Fox Pitt Rivers's house in Dorset. It has recently been found in duplicate, in a private album of images of The Nash as it has stood throughout the twentieth century. That the image depicts personal possessions known to have belonged to Temple, and that it is identical to an H. E. Tidmarsh watercolor of the same scene belonging to the current owner of The Nash, strongly supports this new proposed provenance. I am very grateful to Brenda BennettDavies for bringing this image to my attention.

14. Consider, for example, the search of Temple and his wife, Fanny, in Italy, for "some lovely Venetian table glass which will become [an] heirloom" (Temple to Mrs. Roberts, 16 May 1905).

15. See "Mainly" and "A Brick" for particularly good examples.

16. See also Thomas, who warns against the reduction of the potential uses of artifacts to "a unitary model or process" (26).

\section{WORKS CITED}

Breckenridge, Carol A. "The Aesthetics and Politics of Colonial Collecting: India at World Fairs." Comparative Studies in Society and History 31.2 (Apr. 1989): 195-216.

“A Brick from Nineveh: Sir R. Temple's Burmese Museum for Sale.” Observer 10 Dec. 1922: 9 .

"Celebrities at Home: Colonel Sir Richard Carnac Temple, Bart., CIE, at The Nash, Kempsey." World 20 Sept. 1904: 442-43.

Cohen, Deborah. Household Gods: The British and Their Possessions. New Haven: Yale UP, 2006. 
This text is published as Claire Wintle, "Career development: domestic display as imperial, anthropological and social trophy”, Victorian Studies, 50 (2), 2008, pp. 279-288. ISSN 0042-5222

(http://www.jstor.org/stable/40060327)

Coombes, Annie E. Reinventing Africa: Museums, Material Culture and Popular

Imagination in Late Victorian and Edwardian England. New Haven: Yale UP, 1994.

"Death of Sir Richard Temple." The Times 18 Mar. 1902: 4.

Girouard, Mark. The Victorian Country House. Oxford: Clarendon, 1971.

Jordanova, Ludmilla. “Objects of Knowledge: A Historical Perspective on Museums.” The New Museology. Ed. Peter Vergo. London: Reaktion, 1989. 22-40.

Kuklick, Henrika. The Savage Within: The Social History of British Anthropology, 18851945. Cambridge: Cambridge UP, 1991.

Lane Fox, Augustus Henry. “Observations on Mr. Man's Collection of Andamanese and Nicobarese Objects." Journal of the Anthropological Institute of Great Britain and Ireland 7 (1878): 434-51.

Logan, Thad. The Victorian Parlour: A Cultural Study. Cambridge: Cambridge UP, 2001.

Lorimer, Douglas A. "Race, Science and Culture: Historical Continuities and

Discontinuities, 1850-1914." The Victorians and Race. Ed. Shearer West. Aldershot: Ashgate, 1996. 12-33.

“Mainly about People.” Star 22 June 1922: 4.

Owen, Richard. "On the Osteology and Dentition of the Aborigines of the Andaman Islands, and the Relations Thereby Indicated to Other Races of Mankind." Transactions of the Ethnological Society of London 2 (1863): 34-49.

Pearce, Susan M. On Collecting: An Investigation into Collecting in the European Tradition. London: Routledge, 1995.

Portman, Maurice Vidal. Letter to A. W. Franks. 15 April 1895. Archives of the Department of Prehistory of Europe. British Museum.

---. Letter to Charles Read. 2 March 1895. Archives of the Department of Prehistory of Europe. British Museum.

Sen, Satadru. Disciplining Punishment: Colonialism and Convict Society in the Andaman Islands. New Delhi: Oxford UP, 2000.

Steel, Flora Annie, and Richard Carnac Temple. Wide_Awake Stories: A Collection of tales told by little children, between sunset and sunrise, in the Panjab and Kashmir. Bombay: Education Society's P, 1884.

Stewart, Susan. On Longing: Narratives of the Miniature, the Gigantic, the Souvenir, the Collection. Durham: Duke UP, 1993.

Temple, Richard Carnac. The Legends of the Panjâb. 3 vols. Bombay: Education Society's P, 1884-86. 
This text is published as Claire Wintle, "Career development: domestic display as imperial, anthropological and social trophy”, Victorian Studies, 50 (2), 2008, pp. 279-288. ISSN 0042-5222

(http://www.jstor.org/stable/40060327)

---. Letter to Mrs. Roberts. 17 July 1903. Sir Richard Carnac Temple Papers, MSS EUR F98/67. Asia, Pacific, and Africa Collections. British Library.

---. Letter to Mrs. Roberts. 16 May 1905. Sir Richard Carnac Temple Papers, MSS EUR F98/67. Asia, Pacific, and Africa Collections. British Library.

---. Letter to Mrs. Roberts. 6 January 1914. Sir Richard Carnac Temple Papers, MSS EUR F98/67. Asia, Pacific, and Africa Collections. British Library.

---. Letter to Mrs. Roberts. 29 October 1922. Sir Richard Carnac Temple Papers, MSS EUR F98/67. Asia, Pacific, and Africa Collections. British Library.

---. "Round about the Andamans and Nicobars." Journal of the Society of Arts 48.2457 (1899): 105-25.

---. The Thirty-Seven Nats: A Phase of Spirit-Worship Prevailing in Burma. London: W. Griggs, 1906.

Thomas, Nicholas. Entangled Objects: Exchange, Material Culture, and Colonialism in the Pacific. Cambridge: Harvard UP, 1991.

van Keuren, David K. "Cabinets and Culture: Victorian Anthropology and the Museum Context." Journal of the History of the Behavioral Sciences 25 (Jan. 1989): 26-39.

“Worcester Conference, 1905.” Museums Journal 5.2 (1905): 33-35. 